\title{
ANALISIS PEMBELAJARAN KONSEP ESENSIAL MATEMATIKA SEKOLAH MENENGAH MELALUI PENDEKATAN KONTEKSTUAL SOCRATES
}

\author{
Oleh: \\ Euis Eti Rohaeti \\ Program Studi Pendidikan Matematika STKIP Siliwangi Bandung \\ e2rht@yahoo.com
}

\begin{abstract}
Matematika merupakan ilmu yang terstruktur, dimana untuk menguasai suatu konsep matematika diperlukan penguasaan konsep matematika prasyaratnya. Kenyataan di lapangan penguasaan konsep esensial matematika siswa sekolah menengah masih lemah, dimana mereka kurang memiliki kemampuan pemahaman yang baik terhadap konsep dasar matematika yang berkaitan dengan materi yang akan dibicarakan. Untuk itu dilakukan penelitian untuk menganalisis pembelajaran matematika yang dilakukan oleh guru-guru SMP dan SMA dengan tujuan untuk memperoleh deskripsi tentang kekeliruan penyampaian konsep esensial matematika yang sering dilakukan oleh guru-guru tersebut serta memperbaiki kekeliruan tersebut. Pendekatan yang diterapkan adalah pendekatan kontekstual dengan mengadopsi cara Socrates mengajar murid-muridnya. Socrates mengajar murid-muridnya dengan tanya-jawab yang ditempuh dengan metode induksi dan definisi. Induksi yang menjadi metode Socrates ialah memperbandingkan secara kritis. Dengan melalui induksi sampai kepada definisi, definisi yang dicapai diuji lagi untuk mencapai perbaikan yang lebih sempurna. Hasil penelitian menunjukkan bahwa masih banyak kekeliruan yang dilakukan oleh guru-guru dalam penyampaian konsep-konsep esensial sekolah menengah karena mereka masih terlalu terpaku pada apa yang tertulis pada satu buku teks, tidak pernah melakukan studi komparatif terhadap berbagai sumber belajar, kurang memiliki wawasan yang luas terhadap materi yang sedang dibicarakan, terlalu terpaku kepada kebiasaan mengajar mereka dari waktu ke waktu. Dengan pendekatan Sokrates ini membuat mereka menyadari kekeliruannya, mendiskusikannya untuk perbaikan kekeliruan tersebut, dan membuat mereka termotivasi untuk lebih mengembangkan wawasan pengetahuan mereka.
\end{abstract}

Kata Kunci : konsep esensial matematika, pendekatan kontekstual Sokrates

As a subject teaching at any school level, mathematics is a strictly structured knowledge which requires concept mastery in order to comprehensively understand the subject. However, students at general high school level still find this subject a hard one indicated by their low mastery on the basic concepts of this subject. This study revealed that this fact is closely linked to the way the teachers in both Junior high school and senior high school level teach mathematics. It is found that most teachers involved in this study have mistakenly understood the concept which directly influences their teaching. In other words, the teachers still wrongly understand the basic concept due to their reluctance to use other teaching resources other than texts books they so far use. Adopting the Socrates approach in teaching 
in which question and answer is highly encouraged during the teaching and learning process, this study has been focused on the implementation of the approach resulting in a better understanding of the mathematics basic conceptby the teacher. Through an inductive process in teaching, this study also revealed that the teachers are aware of their wrong understanding upon the concepts of mathematics so far and have higher motivation to further discuss their understanding and widen their knowledge of those concepts crucial in the teaching of mathematics.

Key words: essential mathematics concepts, Socrates contextual approach

\section{A.Pendahuluan}

Matematika merupakan ilmu terstruktur yang terorganisasikan. Hal ini karena matematika dimulai dari unsur yang tidak didefinisikan. Ruseffendi (1991:5) menyatakan bahwa Matematika dimulai dari unsur - unsur yang tidak terdefinisikan (undefined terms, basic terms, primitive terms), kemudian pada unsur yang didefinisikan, ke aksioma / postulat, dan akhir nya pada teorema Selain itu untuk mempelajari matematika, konsep sebelumnya yang menjadi prasyarat, harus benarbenar dikuasai agar dapat memahami topik atau konsep selanjutnya. Karena konsepkonsep matematika tersusun secara hierarkis, terstruktur, logis, dan sistematis mulai dari konsep yang paling sederhana sampai pada konsep yang paling kompleks. Dalam pembelajaran matematika guru seharusnya menyiapkan kondisi siswanya agar mampu menguasai konsep-konsep yang akan dipelajari mulai dari yang sedehana sampai yang lebih kompleks.

Matematika merupakan satu ilmu yang selalu berkembang, baik dari sisi materi maupun manfaatnya bagi masyarakat. Oleh karena itu matematika harus dikuasai peserta didik sejak dini. Dengan menguasai konsep - konsep dasar matematika sejak dini, diharapkan peserta didik akan dapat menguasai ilmu - ilmu yang lain karena matenatika sebagai ilmu tidak hanya untuk matematika itu sendiri, tetapi banyak konsep - konsepnya yang sangat diperlukan oleh ilmu-ilmu lainnya, seperti fisika, kimia, biologi, astronomi, teknik, ekonomi, dan farmasi ( Ruseffendi 1991:88 ). Dengan demikian matematika sangat berpengaruh terhadap penguasaan ilmu - ilmu yang lain.

Konsep esensial Matematika merupakan materi matematika sekolah yang dipelajari oleh siswa-siswa di sekolah (Menurut Soedjadi (1995:1) matematika sekolah adalah bagian atau unsur dari matematika yang dipilih antara lain dengan pertimbangan atau berorentasi pada pendidikan. Dengan demikian dapat disimpulkan bahwa matematika sekolah adalah matematika yang telah dipilah-pilah dan disesuaikan dengan tahap perkembangan intelektual siswa, serta digunakan sebagai salah satu sarana untuk mengembangkan kemampuan berpikir bagi para siswa.

Kenyataan di lapangan kemampuan dasar siswa dalam bermatematika masih lemah. Wahyudin (1999 : 22) mengatakan bahwa salah satu penyebab siswa lemah dalam matematika adalah kurang memiliki kemampuan untuk memahami (pemahaman) 
untuk mengenali konsep-konsep dasar matematika (aksiomatik, definisi, kaidah dan teorema) yang berkaitan dengan pokok bahasan yang sedang dibicarakan.

Untuk mengetahui kesulitan-kesulitan guru dalam mengajarkan konsep-konsep esensial matematika serta kekeliruan guru-guru dalam mengajarkan konsep-konsep tersebut maka penulis mencoba melacaknya dengan menggunakan pendekatan kontekstual Sokrates. Pendekatan ini mengadopsi cara Socrates mengajar muridmuridnya dimana Sokrates mengajar bukan dengan cara menjelaskan, melainkan dengan cara mengajukan pertanyaan untuk menunjukkan kesalahan logika dari jawaban, serta dengan menanyakan lebih jauh lagi, sehingga para siswanya terlatih untuk mampu memperjelas ide-ide mereka sendiri dan dapat mendefinisikan konsep-konsep yang mereka maksud dengan mendetail.

Pada zaman Socrates lembaga pendidikan formal belum ada. Pendidikan waktu itu dilaksanakan pada tempat-tempat pertemuan umum dengan hampir tidak memakai alat belajar sama sekali. Sokrates dan murid-muridnya hanya memanfaatkan pikiran, pembicaraan dan pendengaran saja ditambah obyek-obyek di alam sebagai contoh dan peragaan. Sokrates mengajar murid-muridnya sebagian besar dengan cara bertanya jawab (Pidarta, 1990: 48).

Melalui metode ini para guru diajak bertanya-jawab untuk membimbing dan memperdalam tingkat pemahaman yang berkaitan dengan bahan yang diajarkan sehingga para guru tersebut mendapatkan pemikirannya sendiri dari hasil konflik kognitif yang terpecahkan ( Johnson \& Johnson, 2002). Pendekatan ini merupakan pendekatan kritis dan dialektik; disebut kritis dikarenakan dengan memakai pendekatan ini menuntut orang untuk berpikir kritis dan hasil akhirnya juga bersikap kritis. Sebagai pendekatan dialektika karena menekankan dialog-dialog pemikiran sebagai usaha mengungkapkan sesuatu objek pembahasan menuju pada hakikat terdalamnya (Ennis,1991).

\section{B. Metode Penelitian}

Penelitian ini bertujuan untuk mengidentifikasi kesulitan dan kekeliruan guru dalam mengajarkan topik-topik esensial di sekolah menengah serta mendeskripsikan usahausaha yang harus dilakukan guru untuk mengatasi kesulitan dan memperbaiki kekeliruannya. Penelitian ini merupakan penelitian kualitatif. Subjek penelitian terdiri dari 28 orang guru-guru matematika di SMA dan 39 orang guru-guru matematika di SMP. Data dalam penelitian ini diperoleh melalui observasi, angket, wawancara dengan guru, catatan lapangan dan dokumentasi. Penelitian dilakukan terhadap 9 pokok bahasan SMP dan 8 pokok bahasan SMA.

\section{Hasil Penelitian dan Pembahasan}

Dari hasil tes tertulis, observasi dan wawancara penulisdapat mengemukakan temuan-temuan sebagai berikut: 
1. Kesulitan-Kesulitan Guru dalam Mengajarkan Konsep Esensial Matematika disebabkan oleh:

a. Karakteristik matematika itu sendiri, yaitu objeknya yang abstrak, konsep dan prinsipnya berjenjang, dan prosedur pengerjaannya banyak memanipulasi bentuk-bentuk ternyata menimbulkan kesulitan dalam mengajarkan matematika

b. Banyak siswa yang masih berada dalam taraf berpikir kongkrit. Siswa baru sampai kepemahaman instrumen (instrumental understanding), yang hanya tahu contoh-contoh tetapi tidak dapat mendeskripsikannya. Siswa belum sampai kepemahaman relasi (relational understanding), yang dapat menjelaskan hubungan antar konsep. Akibatnya siswa semakin mengalami kesulitan dalam memahami konsep-konsep lainnya yang diturunkan dari konsep yang belum dikuasainya tadi. Jalan pintasnya ia memberi pengertian sendiri pada konsep-konsep (miskonsepsi).

c. Banyak siswa yang tidak mampu memahami asal-usulnya suatu prinsip. Siswa tahu apa rumusnya dan bagaimana menggunakannya, tetapi tidak tahu mengapanya. Akibatnya, siswa tidak tahu di mana atau dalam konteks apa prinsip itu digunakan.

d. Banyak siswa yang tidak lancar menggunakan operasi dan prosedur. Ketidaklancaran menggunakan operasi dan prosedur terdahulu, berpengaruh lagi pada pemahaman prosedur yang berikutnya.

e. Banyak siswa yang pengetahuannya tidak lengkap. Ketidaklengkapan pengetahuan ini akan menghambat kemampuannya untuk memecahkan masalah matematika. Sementara itu, pelajaran terus berlanjut secara berjenjang, jadilah matematika suatu misteri.

2. Kekeliruan-Kekeliruan Guru dalam Mengajarkan Konsep Esensial Matematika

a. Dalam memberikan pengertian terhadap suatu konsep seringkali guru hanya terpaku pada pengertian yang tertulis di buku tanpa kritis membandingkannya dari berbagai sumber. Contoh pada pengertian Fungsi. Masih banyak guru yang menuliskan Fungsi dari himpunan A ke B adalah Relasi khusus yang memetakan setiap anggota A dengan tepat satu anggota B. Setelah didiskusikan dengan pendekatan kontekstual Sokrates, akhirnya para guru menyadari kekeliruannya bahwa kata khusus itu tidak perlu karena sudakh tersirat dari kata "setiap" dan "tepat satu".

b. Masih banyak guru yang sistematika mengajarnya mengikuti alur yang ada di buku, sehingga seringkali konsep yang diperoleh siswa terpisah-pisah dan kurang dapat menghubungkan antara suatu konsep dengan konsep yang lainnya. Contohnya pada pokok bahasan segiempat, banyak guru yang menjelaskannya bangun per bangun tidak dalam satu kesatuan dulu misalnya dari bagan yang menunjukkan hubungan antar bangun segiempat tersebut, kemudian dari bagan tersebut menuju ke pengertian dan ciri-ciri bangun tersebut. 
c. Materi seringkali tidak membumi, tidak dimulai dengan masalah kontekstual yang merupakan konsep yang sudah dikenal siswa untuk mengantarkannya ke materi baru. Padahal di dalam KTSP pembelajaran matematika dianjurkan untuk dimulai dengan pengenalan masalah yang sesuai dengan situasi (contextual problem). TIM Kurikulum (2007:1) mengatakan bahwa dengan mengajukan masalah kontekstual, peserta didik secara bertahap dibimbing menguasai konsep matematika. Dengan demikian pembelajaran matematika diharapkan berakhir dengan sebuah pemahaman siswa yang komprehensif dan holistik. Disamping itu pembelajaran matematika hendaknya bermakna, yaitu pembelajaran yang mengutamakan pengertian atau pemahaman konsep dan penerapannya dalam kehidupan.

d. Guru-guru terlalu terpaku pada cara menyelesaikan soal pada yang sudah terbiasa ada di buku teks tanpa kreatif membandingkan dengan sumber lain, serta seringkali tidak memperhitungkan tahap berpikir siswanya. Contoh pada soal berikut:

Dari soal:

Tentukan persamaan garis yang bergradien 2 dan melalui titik $(3,1)$

Guru-guru terbiasa menerangkannya dengan cara sebagai berikut:

Diketahui $\mathrm{m}=2, \mathrm{x}_{1}=3, \mathrm{y}_{1}=1$

$\mathrm{y}-\mathrm{y}_{1}=\mathrm{m}\left(\mathrm{x}-\mathrm{x}_{1}\right)$

$\mathrm{y}-1=2(\mathrm{x}-3)$

$\mathrm{y}-1=2 \mathrm{x}-6$

$y=2 x-6+1$

$\mathrm{y}=2 \mathrm{x}-5$

Dan nyaris tidak ada yang menjelaskan dengan cara berikut:

Diketahui $\mathrm{m}=2, \mathrm{x}=3, \mathrm{y}=1$

$\mathrm{y}=\mathrm{mx}+\mathrm{c}$

$1=2.3+\mathrm{c}$

$1=6+\mathrm{c}$

$\mathrm{c}=-5$

Jadi $y=2 x-5$

e. Seringkali guru-guru tidak berani langsung ke pembelajaran dengan membedakan. Contohnya ketika mengajarkan konsep perbandingan mereka menerangkannya satu-satu mulai dari perbandingan senilai, kemudian perbandingan berbalik nilai. Tidak langsung mulai dari contoh yang mengkontraskan antara perbandingan senilai dan berbalik nilai.

f. Metode atau pendekatan mengajar yang digunakan seringkali monoton dan kurang variatif, tidak melihat karakteristik dari materi pelajaran dan karakteristik peserta didik. 


\section{Kesimpulan}

Di dalam sistem pembelajaran, komponen yang satu dengan yang lainnya harus saling berhubungan dan mendukung. Siswa sebagai input dan guru sebagai instrumental input harus bersinergi untuk tercapainya tujuan pembelajaran. Kesulitan-kesulitan yang dihadapi guru dalam mengajarkan konsep esensial matematika dapat diatasi dengan dukungan dari siswa untuk mau memperbaiki kekurangan dirinya dan mempunyai motivasi yang kuat untuk belajar. Guru pun harus menciptakan suasana kelas yang kondusif melalui metode mengajar yang bervariatif dan menarik yang mendorong minat dan motivasi siswa untuk belajar. Untuk meluruskan kekeliruan guru dalam mengajarkan konsep-konsep esensial matematika perlu adanya pertemuan rutin dengan guru-guru lain di bawah bimbingan seorang ahli agar dapat berbagi pengalaman tentang cara mengajarkan konsep tersebut dengan benar.

\section{E. Daftar Pustaka}

Ennis, R.H (1991). An Elaboration of Cardinal goal of Science Instruction, Educational Philosophy and Theory 23(1), 31-43.

Johnson, D.W \& Johnson, R.T (2002). The Meaningful Assessing A Manageable and Cooperative Process. Boston: Allyn and Bacon.

Pidarta, M (1990). Cara Belajar Mengajar di Universitas Negara Maju. Jakarta : Bina Aksara.

Ruseffendi,E.T.(1991). Pengantar kepada Membantu Guru Mengembangkan Kompetensinya dalam Pengajaran Matematika untuk Meningkatkan CBSA. Bandung: Tarsito.

Soedjadi et al (1995). Mari Berhitung. Jakarta: Balai Pustaka.

Tim KTSP (2007). Kurikulum Tingkat Satuan Pendidikan. Jakarta: Depdiknas.

Wahyudin (1999). Kemampuan Guru Matematika, Calon Guru Matematika, dan Siswa dalam Mata Pelajaran Matematika. Disertasi pada PPS UPI: tidak diterbitkan 